\title{
Fabrication of A Superhydrophobic Surface with Silica Nanoparticles and Polytetrafluoroethylene
}

\section{Somaiyeh JAFARPOUR ${ }^{1 *}$ and Mehmet ERTUGRUL ${ }^{2}$}

$1^{*}, 2$ Department of Nanoscience and Nanoengineering, Atatürk University, Erzurum, Turkey

${ }^{2}$ Nanoscience and Nanoengineering Application and Research Center, Atatürk University, Erzurum, Turkey

${ }^{2}$ Department of Electrical and Electronics Engineering, Atatürk University, Erzurum, Turkey

(Geliş Tarihi/Received: 09.09.2015, Kabul Tarihi/Accepted: 08.10.2015)

\begin{abstract}
In this paper we fabricate a superhydrophobic surface with Silica nanoparticles and Poly tetrafluoroethylene (PTFE) by using spin coating and microwave plasma treatment on the glass substrate. During the spin coating, the effect of rotation speed on superhydrophobicity is investigated and the optimum rotation speed with high contact angle is identified. It is found that the reaction of PTFE by microwave argon plasma yields a superhydrophobic surface with contact angle of $163^{\circ}$ which is more than the contact angle of the surface without microwave plasma coating. The hydrophobicity of the surface is explained based on Wenzel and Cassie-Baxter regime. The characterization of the rough structure including $\mathrm{SiO} 2$ nanoparticles aggregates coated by PTFE is carried out by Scanning Electron Microscopy (SEM), Contact Angle (CA) by contact angle goniometer with deionized water at room temperature.
\end{abstract}

Keywords: Superhydrophobic, Microwave plasma, Spin coating, Silicon dioxide

Silika Nanoparçacik ve Politetraforoetilen Kullanarak Süperhidrofobik Yüzey Fabrikasyonu

\section{ÖZET}

Bu çalışmada silika nanoparçacıkları ve Poly tetrafluoroethylene (PTFE) ile döndürmeli kaplama ve mikrodalga plazma kullanarak cam alttaş üzerine süperhidrofobik yüzey fabrikasyonu gerçekleştirilmiştir. Döndürmeli kaplama süresince süperhidrofobiklik üzerine döndürme hızı incelenmiş ve en büyük temas açısı için en iyi döndürme hızı belirlenmiştir. Argon ortamında mikrodalga plazmanın etkisiyle PTFE kaplı yüzeyin temas açısının 1630 ile mikrodalga plazma uygulanmadığı duruma göre daha yüksek olduğu tespit edilmiştir. Hibrofobiklik, Wenzel ve CassieBaxter durumuna uyduğu görülmüştür. Üzerine PTFE kaplı SiO2 nanoparcacıklar içeren yüzeyin karakterizasyonu Taramalı Elektron Mikroskopu (SEM) ile ve oda sıcaklığında de iyonize su kullanarak temas açısı (CA) ölçümleri yapılmıştır.

Anahtar Kelimeler: Süperhidrofobik, Mikrodalga plazma, Döndrürmeli Kaplama, Sisliyum dioksit

\section{Introduction}

Wettability of a surface is one of the important properties of a material which is introduced by "hydrophobicity" term. A surface is hydrophobic when, the contact angel between surface and water is larger 
than $90^{\circ}$, while the contact angel is greater than $150^{\circ}$ it is ultra-hydrophobic which is called superhydrophobic (Ramaratnam et al., 2008). On a superhydrophobic surface a droplet place as a circle on the surface and in some cases the surface will repel the droplet (Jung, 2009). Superhydrophobic surfaces have many applications in industry such as corrosion, self-cleaning materials, anti-icing, micro-fluidics, oxidation and other applications (Foroughi Mobarakeh, Jafari, \& Farzaneh, 2011). Depending on the applications, there are various methods to create superhydrophobic surfaces like: including plasma treatment, lithography, sol-gel process, chemical vapor deposition, electrospinning, and colloidal assemblies (Gao, Yan, Chen, \& Mee, 2011). Surface roughness and surface chemistry are two important factors in fabricating a superhydrophobic surface (Xue, Jia, Zhang \& Ma, 2010). Hence, these surfaces prepared during a two-step process, surface roughness creation and coating with low surface tension materials (Momen \& Farzaneh, 2012). There are some regimes that explain the factors. Wenzel regime that indicates the roughness and Cassie-Baxter model that indicates the low surface energy materials in superhydrophobic surfaces. Nanoparticles, especially Silica nanoparticles are used to create roughness on a surface (He et al., 2012). Silica nanoparticles can create hierarchical structure with nano and microscale roughness on a surface (Gao et al., 2011). Many polymers are hydrophobic, Fluorocarbons such as Teflon are materials with low surface energy, these materials are thermally and UV stable and can be used in waterproof clothing, concrete and paint with very low friction in water (Irzh, Ghindes, \& Gedanken, 2011). In this study we prepare a hierarchical superhydrophobic surface including micro and nanostructure from $\mathrm{SiO}_{2}$ and PTFE by of Plasma coating and without MW (Microwave) Plasma coating.

\section{Materials and Methods}

PTFE spray which is for lubrication in industry application, Silica $\left(\mathrm{SiO}_{2}\right)$ nanoparticles (fumed powder, Aldrich) with mix of two different average sizes $(5 \mathrm{~nm}$ and $15 \mathrm{~nm}$ ) are used in this study. Handmade spin coating and domestic microwave oven (100oW, Kenwood) including a drilled hole in its down part, a plasma chamber made from Pyrex, an argon cylinder, a vacuum pump is applied as a reaction system.

Glass substrates were cleaned during 3 cleaning process, first ultrasonically cleaned in acetone and distilled water, the dried and cleaned in piranha solution and at last cleaned by HF solution to remove oxides on the surface.

Silica suspension was prepared by adding $0.3 \mathrm{mg}$ of $\mathrm{SiO}_{2}$ nanoparticles in $10 \mathrm{ml}$ toluene. Then the suspension was sonicated for 1 hour. The prepared suspension was coated on the clean dry glass substrates by spin coating in different rotation speed. The wettability of these coatings was investigated using water droplets by Kruss contact angle goniometer to measure the contact angle. Then prepared solution of PTFE in toluene (\%w/v) was spin coated on rough glass slides deposited by silica nanoparticles. Then 
substrates divided into two groups, first group after spin coating process were placed in high vacuum system for $30 \mathrm{~min}$ and then dried in oven for 2 hours in $120^{\circ} \mathrm{C}$, the second group after spin coating process were placed in microwave plasma chamber for plasma treatment, schematic illustration of the reaction system is shown at Figure 1, the vacuum pump start working the pressure inside the chamber down to $1 \times 10^{-2}$ Torr, argon was pumped through the chamber for $15 \mathrm{~s}$, then the microwave activated in order to plasma treatment for about $5 \mathrm{~s}$.

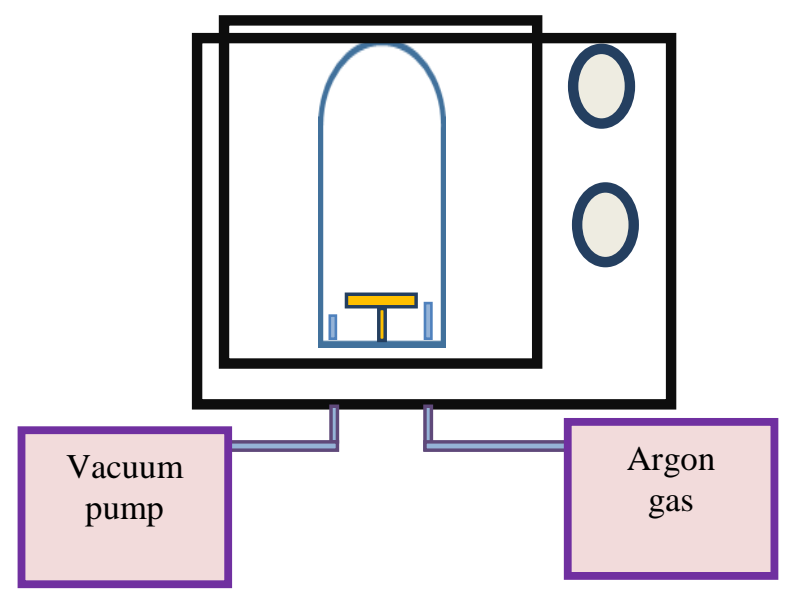

Figure 1. Schematic illustration of the reaction system.

The treated glasses by microwave plasma placed in high vacuum for 30 min and then dried in oven the same as the first group.

\section{Results and Discussion}

We investigate the surface hydrophobicity of different rotation coatings according to the Table 1, the effect of spin coating rotation in surface roughness is depicted in Figure 2. The contact angle measurements show that the contact angle increases by increasing the rotation speeds. By increasing the speed, dispersion of $\mathrm{SiO}_{2}$ nanoparticles, so the film thickness is decreases after $2500 \mathrm{rpm}$.

Table 1. Spin coating rotation speed effect in hydrophobicity.

\begin{tabular}{cccc}
\hline Sample & $\begin{array}{c}\mathbf{S i O}_{\mathbf{2}} \\
(\mathbf{m g}) /\end{array}$ & $\begin{array}{c}\text { Rotation } \\
(\mathbf{m l})\end{array}$ & $\begin{array}{c}\text { Contact } \\
\text { (rpm) } \\
\mathbf{( o )}\end{array}$ \\
\hline $\mathbf{1}$ & 0.3 & 500 & 126 \\
$\mathbf{2}$ & 0.3 & 1000 & 135 \\
$\mathbf{3}$ & 0.3 & 1500 & 145 \\
$\mathbf{4}$ & 0.3 & 2000 & 151 \\
$\mathbf{5}$ & 0.3 & 2500 & 155 \\
$\mathbf{6}$ & 0.3 & 3000 & 150 \\
$\mathbf{7}$ & 0.3 & 3500 & 140 \\
\hline
\end{tabular}

After spin coating with PTFE with concentration of $1 \% \mathrm{w} / \mathrm{v}$, contact in each rough surface increased because of coating by low surface energy PTFE. Plasma treatment of the same surfaces coated with $\mathrm{SiO}_{2}$ nanoparticles showed about 4 degrees increase in contact angle. The water droplets easily roll off the surface coated in $2500 \mathrm{rpm}$ and treated by Microwave Plasma coating. We find out that the hydrophobicity property

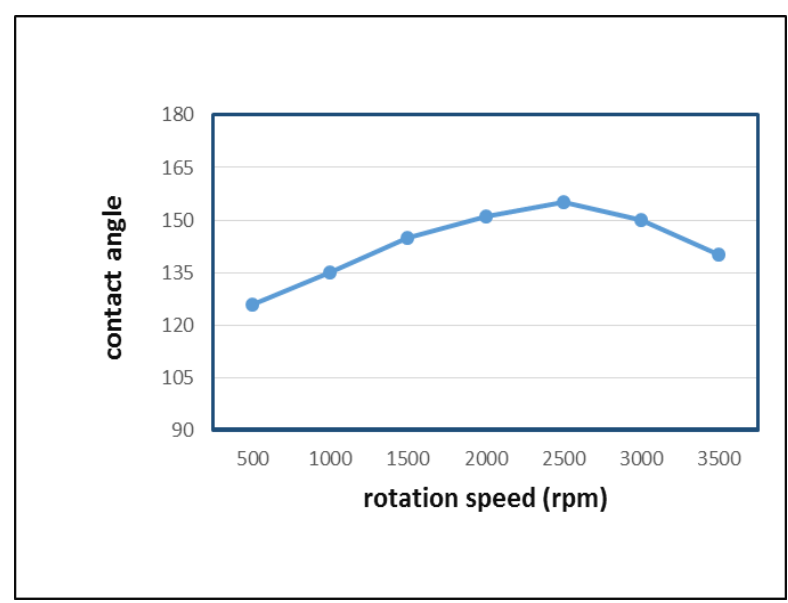

Figure 2. Contact angle relation with roughness in different rotation speeds 


\begin{tabular}{|c|c|c|c|c|}
\hline \multirow{3}{*}{$\begin{array}{l}\text { of the surfaces turns into } \\
\text { superhydrophobicity and rolling property. } \\
\text { In surfaces coated in } 2500 \mathrm{rpm} \text { and } \\
\text { treated with Microwave Plasma, micro and } \\
\text { nanoscale structure created because of the } \\
\text { aggregation of silica nanoparticles. The } \\
\text { aggregation in this rpm results in suitable } \\
\text { roughness with good thickness. }\end{array}$} & \multicolumn{2}{|c|}{$\begin{array}{l}\text { Table 2. Contact } \\
\text { before and after } \\
\text { treatment. }\end{array}$} & \multicolumn{2}{|c|}{$\begin{array}{l}\text { angle measurements } \\
\text { microwave plasma }\end{array}$} \\
\hline & Sample & $\begin{array}{c}\text { Rotation } \\
\text { (rpm) }\end{array}$ & $\begin{array}{c}\text { Contact } \\
\text { Angle } \\
\text { (o) } \\
\text { before } \\
\text { MW } \\
\text { plasma }\end{array}$ & $\begin{array}{c}\text { Contact } \\
\text { Angle } \\
(\mathbf{o}) \\
\text { after } \\
\text { MW } \\
\text { plasma } \\
\end{array}$ \\
\hline & 1 & 500 & 127 & 128 \\
\hline Superhydrophobicity enhanced by creating & 2 & 1000 & 138 & 139 \\
\hline the micro and nano hierarchical structures. & 3 & 1500 & 146 & 150 \\
\hline SEM images of the surfaces in Figure 3 show & 4 & 2000 & 153 & 155 \\
\hline the surface hierarchical structure. & 5 & 2500 & 159 & 163 \\
\hline After spin coating by PTFE the & 6 & 3000 & 152 & 153 \\
\hline contact angle incre & 7 & 3500 & 143 & 147 \\
\hline
\end{tabular}

without microwave plasma treatment. After MW plasma treatment the contact angle increased about 4 degrees for some surfaces according to the Table 2.

The change in contact angle and change increasing in hydrophobicity property into superhydrophobicity and water repelling property after microwave plasma coating shows that the hydrophobicity before coating with PTFE follows the Wenzel regime which indicated just for roughness but after coating with PTFE and increase in hydrophobicity shows the change of Wenzel regime into Cassie-Baxter regime because of air trapped between roughness and reduce the adhesion between droplets and surface.

The change in contact angle and change increasing in hydrophobicity property into superhydrophobicity and water repelling property after microwave plasma coating shows that the hydrophobicity before coating with PTFE follows the Wenzel regime which indicated just for roughness but after coating with PTFE and increase in hydrophobicity shows the change of Wenzel regime into Cassie-Baxter regime because of air trapped between roughness and reduce the adhesion between droplets and surface. It means that hierarchical structure of roughness is the main factor of change in Wenzel model into Cassie-Baxter model.

It means that hierarchical structure of roughness is the main factor of change in Wenzel model into Cassie-Baxter model. 


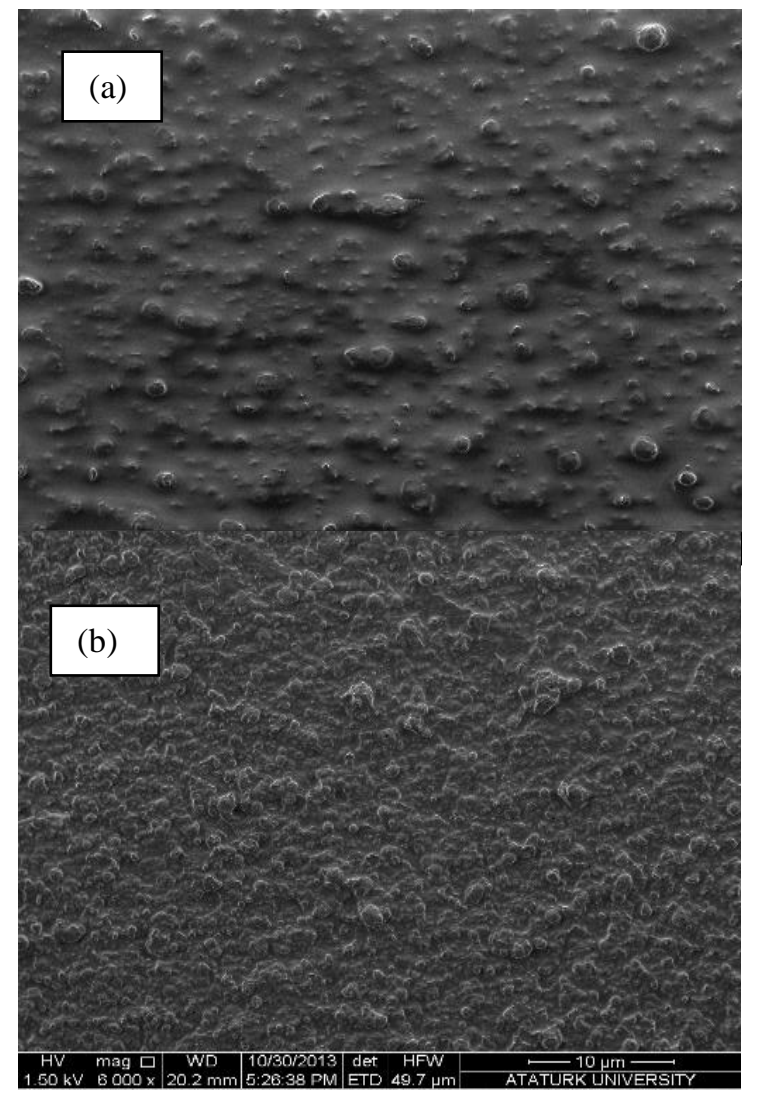

Figure 3. SEM image of $500 \mathrm{rpm}$ rotation speed coating (a), SEM image of optimum 2500 rpm rotation speed coating (b)

\section{Conclusion}

This paper presents a simple method to fabricate a superhydrophobic coating on a glass surface. For $0.3 \mathrm{mg}$ solution of silica nanoparticles the largest contact angle is observed when the rotation speed of coating is $2500 \mathrm{rpm}$ while hierarchical structure is created and superhydrophobic property of this surface increased up to 159 after coating by PTFE and water repellency property is observed in this surface after microwave plasma treatment.

\section{References}

Foroughi Mobarakeh, L., Jafari, R., \& Farzaneh, M. 2011. Superhydrophobic
Surface Elaboration Using Plasma Polymerization of Hexamethyldisiloxane (HMDSO). Advanced Materials Research, 409, $783-787$.

Gao, N., Yan, Y. Y., Chen, X. Y., \& Mee, D. J. 2011. Superhydrophobic surfaces with hierarchical structure. Materials Letters, 65(19-20), 2902-2905. Elsevier B.V. Retrieved from http://dx.doi.org/10.1016/j.matlet.2011 .06 .088 .

He, Z., Ma, M., Xu, X., Wang, J., Chen, F., Deng, H., Wang, K., et al. 2012. Fabrication of superhydrophobic coating via a facile and versatile method based on nanoparticle aggregates. Applied Surface Science, 258(7), 25442550. Elsevier B.V. Retrieved from http://dx.doi.org/10.1016/j.apsusc.2011 .10 .090 .

Irzh, A., Ghindes, L., \& Gedanken, A. 2011. Rapid deposition of transparent superhydrophobic layers on various surfaces using microwave plasma. ACS Applied Materials and Interfaces, 3(12), 45664572.

Momen, G., \& Farzaneh, M. 2012. A ZnObased nanocomposite coating with ultra water repellent properties. Applied Surface Science, 258(15), 5723-5728. Elsevier B.V. Retrieved from http://dx.doi.org/10.1016/j.apsusc.201 2.02.074. 
Jung, C. Y. 2009. Natural and Biomimetic Artificial Surfaces for Superhydrophobicity, Self-Cleaning, Low Adhesion, and Drag Reduction Dissertation.

Ramaratnam, K., Iyer, S. K., Kinnan, M. K., Chumanov, G., Brown, P., \& Luzinov, I. 2008. Ultrahydrophobic textiles: Lotus approach. AATCC Review, 8(1), 42-48.

Xue, C. H., Jia, S. T., Zhang, J., \& Ma, J. Z. 2010. Large-area fabrication of superhydrophobic surfaces for practical applications: an overview. Science and Technology of Advanced Materials, 11(3), 033002. 